(2) Open Access Full Text Article

\title{
Freezing adversely affects measurement of vascular endothelial growth factor levels in human aqueous samples
}

This article was published in the following Dove Press journal:

Clinical Ophthalmology

I0 January $201 \mathrm{I}$

Number of times this article has been viewed

\section{Sankarathi Balaiya \\ Sandeep Grover \\ Ravi K Murthy \\ Kakarla $\vee$ Chalam}

Department of Ophthalmology, University of Florida College of Medicine, Jacksonville, FL, USA
Correspondence: Kakarla $\vee$ Chalam Department of Ophthalmology, University of Florida College of Medicine, 580 West 8 th street, Tower-2, Jacksonville, FL 32209, USA

Tel + I 904244936 |

Fax + I 904244 939।

Email kchalam@jax.ufl.edu
Purpose: Aqueous levels of vascular endothelial growth factor (VEGF) can be a surrogate marker of intraocular VEGF activity and a measure of efficacy of anti-VEGF treatment in a variety of vasoproliferative retinal disorders, including diabetic retinopathy, age-related macular degeneration, and central retinal vein occlusion. Measurement of the VEGF level may be adversely affected by premeasurement variables, such as freezing and delay, in sample analysis. We aim to evaluate the effect of storage and delayed measurement of human aqueous VEGF levels in these conditions.

Methods: Aqueous samples collected from patients receiving intravitreal injection of bevacizumab for various retinal diseases were divided into two groups. In Group 1, the VEGF levels were analyzed on the same day; in Group 2, the VEGF levels were analyzed after 21 days of freezer storage $\left(-80^{\circ} \mathrm{C}\right)$ using immunobead assay. Statistical comparison using a paired $t$-test was performed between the two groups.

Results: Thirty-one aqueous humor samples were collected, and the VEGF concentration for fresh samples was $7.8 \pm 5.9 \mathrm{pg} / \mathrm{mL}$ (mean $\pm \mathrm{SD}$ ) compared to $6.5 \pm 6.0 \mathrm{pg} / \mathrm{mL}$ in frozen samples, resulting in a statistically significant difference $(P=0.03)$.

Conclusions: Accurate measurement of the VEGF level is a vital component of clinical decision-making. Delayed analysis of VEGF levels in aqueous samples may result in significant sample degradation and lower levels of measured VEGF.

Keywords: VEGF level, aqueous humor, immunobead assay, VEGF storage

\section{Introduction}

Vascular endothelial growth factor (VEGF), an endothelial cell mitogen, is implicated as a key factor in angiogenesis and increases vascular permeability. ${ }^{1,2}$ Increased levels of VEGF are observed in aqueous and vitreous humor in several ischemic ocular conditions, including diabetic retinopathy, retinal vascular occlusions, and age-related macular degeneration. As such, VEGF levels correlate with the severity of the disease process. ${ }^{3-10}$ Accurate assessment of VEGF in aqueous samples can be a useful tool in assessing the severity of disease, as well as in titrating the dosage of anti-VEGF therapy.

The most widely used enzyme-linked immunosorbent assay (ELISA) that measures VEGF levels in the aqueous samples analyzes one cytokine and requires a sample volume of at least $100 \mu \mathrm{L}$ for detection of proteins such as VEGF. ${ }^{11}$ Recent cytometric bead immunoassay measurement of VEGF levels in aqueous samples has shown superior accuracy in smaller volumes. ${ }^{6,12}$ Use of bead-based immunoassay is more accurate and cost effective than use of ELISA in measuring VEGF levels. ${ }^{13}$ 
Aqueous samples are typically frozen at $-80^{\circ} \mathrm{C}$ (a common clinical practice) if immediate measurement of cytokine is not feasible. Extrinsic factors, such as temperature, can alter the measurement of cytokine levels in biological fluids after storage. ${ }^{14,15}$ In this study, we compared the VEGF levels estimated in a fresh sample with VEGF levels stored for 21 days at $-80^{\circ} \mathrm{C}$ and evaluated the effect of freezing on sample degradation using bead-based immunoassay.

\section{Methods}

\section{Sample collection}

The study samples were obtained from 31 patients (mean age \pm SD, $73.87 \pm 9.29$ years; male/female, $15 / 16$ ) who were receiving intravitreal injection of bevacizumab for various retinal diseases. Of these, 18 patients had macular degeneration, ten had cystoid macular edema, and three had diabetic macular edema. One hundred microliters of aqueous humor samples were obtained from the eye before administration of intravitreal injection. All samples were obtained with informed consent from the patient and approved by the institutional review board at the University of Florida.

Each sample was aliquoted into two subgroups. VEGF analysis was performed on the same day on samples that obtained from participants in Group 1. Samples from Group 2 were stored in a $-80^{\circ} \mathrm{C}$ freezer and analyzed after 3 weeks (21 days). All samples were stored in 1.5-mL self-standing screw cap polypropylene tubes (DNAse, RNAse, and pyrogen free). The samples that were processed on the same day were referred as 'fresh', and the samples stored at $-80^{\circ} \mathrm{C}$ were referred as 'frozen'.

\section{Usage of immunobead assay for VEGF analysis}

Both fresh and frozen samples were handled by the same experienced researcher. Samples were processed for VEGF analysis at room temperature (RT) using immunobead assay by Luminex $100^{\mathrm{TM}}$ IS fluoroanalyzer (Tepnel Life Sciences, San Diego, CA). Standards were reconstituted and serially diluted as per manufacturer's instructions (Invitrogen Corporation, Carlsbad, CA). To each well of 96-well microtiter plates, $25 \mu \mathrm{L}$ of polystyrene microbeads and wash solutions were added and incubated for $30 \mathrm{sec}$. After the incubation time, the supernatant was washed off using vacuum manifold, followed by the addition of incubation buffer and $50 \mu \mathrm{L}$ each of sample and assay diluent. Diluted standards were added to the designated wells and the plate was incubated for $2 \mathrm{~h}$ at RT on an orbital shaker at $250-500 \mathrm{rpm}$. After incubation, the liquid was removed and the excess beads were washed off.
Furthermore, $100 \mu \mathrm{L}$ of detector antibody was added to each well and incubated on an orbital shaker at RT for $1 \mathrm{~h}$. Excess detector antibodies were removed, followed by the addition of substrate complex (Streptavidin R-Phycoerythrin [S-RPE]), and the fluorescence was measured using Luminex 100 IS fluoroanalyzer after $30 \mathrm{~min}$ of incubation at RT. Both negative and positive controls were included on each microtiter plate for each reaction. To ensure proper assay performance, a known concentration of human recombinant VEGF was included in each run (positive control).

\section{Analysis of VEGF concentration}

We measured the mean fluorescence of associated S-RPE with 100 beads that were bound to the VEGF in the sample. The resulting data was interpreted by curve-fitting algorithm using InStat data analysis software (GraphPad, San Diego, CA). VEGF levels were estimated based on the intensity of emitted fluorescence in each sample. Sample concentrations were expressed as $\mathrm{pg} / \mathrm{mL}$ based on standard curves plotted using protein standards supplied with the kits (minimal detectable limit is $5.7 \mathrm{pg} / \mathrm{mL}$; Invitrogen Corporation). The effect of dilution was corrected in determining final values.

\section{Statistical analysis}

Statistical analysis was done using GraphPad InStat and Minitab 13 (Minitab, State College, PA) statistical packages. A paired $t$-test was used to compare the VEGF concentration between the fresh and the frozen samples. The level of statistical significance was set at $P<0.05$.

\section{Results}

In our study, we analyzed 31 fresh and frozen aqueous humor samples to observe the difference in VEGF concentration. Using this immunobead assay, we were able to detect the VEGF levels in all the samples (Table 1). The mean VEGF concentration in the fresh samples was $7.8 \pm 5.9 \mathrm{pg} / \mathrm{mL}$ (mean $\pm \mathrm{SD}$; range: $1.12-25.4 \mathrm{pg} / \mathrm{mL}$ ) compared with $6.5 \pm 6.0 \mathrm{pg} / \mathrm{mL}$ (range: $0.60-23.74 \mathrm{pg} / \mathrm{mL}$ ) for the frozen samples (average of $17 \%$ reduction after freezing for 21 days).

Of the 31 samples analyzed, 24 samples showed more than $10 \%$ variation in VEGF levels after storage at $-80^{\circ} \mathrm{C}$ compared with the fresh samples. Nineteen samples showed decreased VEGF levels and 12 samples showed increased VEGF levels after storage at $-80^{\circ} \mathrm{C}$. The observed difference was statistically significant in frozen samples in comparison with VEGF concentration in the fresh samples $(P=0.03$; Figure 1). Table 2 shows the fresh and frozen aqueous individual and mean VEGF levels based on the clinical diagnoses. 
Table I VEGF levels in aqueous measured fresh and after storage at $-80^{\circ} \mathrm{C}$ for 21 days

\begin{tabular}{|c|c|c|c|c|c|}
\hline Sample no. $(n=31)$ & Diagnosis & $\begin{array}{l}\text { Fresh VEGF levels } \\
\text { on day I (pg/mL) }\end{array}$ & $\begin{array}{l}\text { Frozen VEGF levels } \\
\text { on day } 2 \mathrm{I}(\mathrm{pg} / \mathrm{mL})\end{array}$ & Difference & $\begin{array}{l}\text { Percentage change } \\
\text { from day I }\end{array}$ \\
\hline I & MD & 5.60 & 0.60 & -5.01 & -89.36 \\
\hline 2 & CME & 6.80 & 5.22 & -1.59 & -23.34 \\
\hline 3 & MD & 9.21 & 1.59 & -7.62 & -82.73 \\
\hline 4 & CME & 8.41 & 5.47 & -2.94 & -34.99 \\
\hline 5 & CME & $12.0 \mid$ & 7.75 & -4.26 & -35.48 \\
\hline 6 & MD & 2.11 & 2.00 & -0.10 & -4.94 \\
\hline 7 & MD & 1.33 & 1.334 & +0.00 & +0.30 \\
\hline 8 & $M D$ & 6.26 & 1.73 & -4.53 & -72.39 \\
\hline 9 & MD & 6.35 & 2.83 & -3.52 & -55.46 \\
\hline 10 & MD & 7.47 & 2.28 & -5.20 & -69.54 \\
\hline II & CME & 1.12 & 0.63 & -0.49 & -43.93 \\
\hline 12 & DME & 25.40 & 8.17 & -17.23 & -67.84 \\
\hline 13 & CME & 17.81 & 19.41 & +1.61 & +9.03 \\
\hline 14 & MD & 2.12 & 2.69 & +0.57 & +26.79 \\
\hline 15 & MD & 2.04 & 1.93 & -0.11 & -5.29 \\
\hline 16 & MD & 3.06 & 3.53 & +0.46 & +15.14 \\
\hline 17 & $M D$ & 2.04 & 2.90 & +0.86 & +42.06 \\
\hline 18 & DME & 3.95 & 3.00 & -0.95 & -23.96 \\
\hline 19 & MD & 13.77 & 10.32 & -3.45 & -25.04 \\
\hline 20 & $M D$ & 4.20 & 2.93 & -1.27 & -30.17 \\
\hline 21 & CME & 4.94 & 3.08 & -1.86 & -37.68 \\
\hline 22 & CME & 17.45 & 23.74 & +6.29 & +36.07 \\
\hline 23 & CME & 13.04 & 11.24 & -1.80 & -13.80 \\
\hline 24 & DME & 13.42 & 16.04 & +2.62 & +19.54 \\
\hline 25 & $M D$ & $|7.3|$ & 17.86 & +0.55 & +3.18 \\
\hline 26 & $M D$ & 4.06 & 4.63 & +0.57 & +13.94 \\
\hline 27 & CME & 5.99 & 8.00 & +2.01 & +33.60 \\
\hline 28 & $M D$ & 2.52 & 2.51 & -0.01 & -0.48 \\
\hline 29 & $M D$ & 8.27 & 11.50 & +3.23 & +39.01 \\
\hline 30 & CME & 4.54 & 3.63 & -0.90 & -19.93 \\
\hline 31 & $M D$ & 11.84 & $13.0 \mid$ & +1.17 & +9.90 \\
\hline
\end{tabular}

Abbreviations: MD, macular degeneration; CME, cystoid macular edema; DME, diabetic macular edema; VEGF, vascular endothelial growth factor.

\section{Discussion}

Anti-VEGF therapy, in the form of intravitreal injection, is the mainstay of therapy in the management of ischemic ocular conditions. VEGF levels in ocular fluids provide indirect evidence of severity of disease process and help

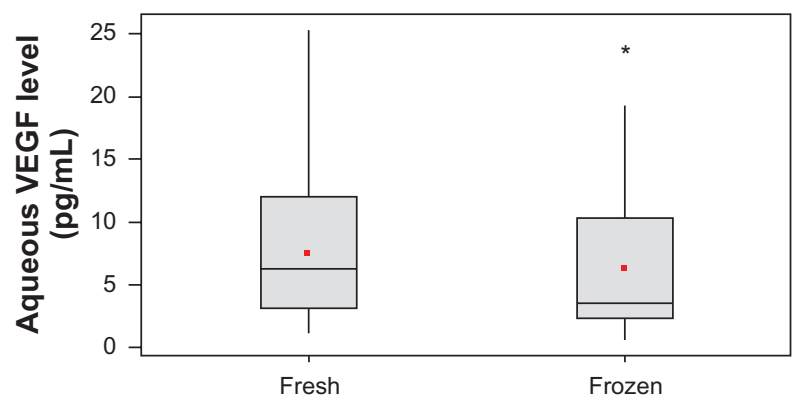

Figure I Comparative analysis of vascular endothelial growth factor (VEGF) concentration between fresh and frozen samples.

Note: Mean values are represented by solid red circles. in monitoring the therapeutic effects of anti-VEGF agents. Vitreous levels of secreted proteins or drugs have been used as a surrogate for retinal and choroidal levels, but vitreous taps or biopsies are not risk free and are usually obtained from patients undergoing surgery for different reasons. The use of an anterior chamber tap, at the time of intravitreal injection, to decompress the vitreous cavity has been found to be well tolerated. Studies are evaluating the potential usefulness of incorporating anterior chamber taps into clinical trials for measurement of molecular targets and drug levels (personal communication, DRCR.net).

Traditionally, ELISA is used to measure VEGF levels in the aqueous samples. Bead-based assay is fast replacing ELISA for use in laboratories to quantify cytokines in biological samples, such as serum, as bead-based assay is quicker to perform and is more efficient and cost effective. ${ }^{11,12}$ The increased surface area provided by the microbeads 
Table 2 Vascular endothelial growth factor (VEGF) levels in aqueous samples measured fresh and after storage at $-80^{\circ} \mathrm{C}$ for 21 days based on clinical diagnosis

\begin{tabular}{|c|c|c|c|c|c|c|}
\hline \multirow[t]{2}{*}{ Serial no. } & \multicolumn{2}{|c|}{ Macular degeneration } & \multicolumn{2}{|c|}{ Cystoid macular edema } & \multicolumn{2}{|c|}{ Diabetic macular edema } \\
\hline & $\begin{array}{l}\text { Fresh VEGF } \\
\text { levels on } \\
\text { day I }(\mathrm{pg} / \mathrm{mL})\end{array}$ & $\begin{array}{l}\text { Frozen VEGF } \\
\text { levels on } \\
\text { day } 21(\mathrm{pg} / \mathrm{mL})\end{array}$ & $\begin{array}{l}\text { Fresh VEGF } \\
\text { levels on } \\
\text { day I }(\mathrm{pg} / \mathrm{mL})\end{array}$ & $\begin{array}{l}\text { Frozen VEGF } \\
\text { levels on } \\
\text { day } 21(\mathrm{pg} / \mathrm{mL})\end{array}$ & $\begin{array}{l}\text { Fresh VEGF } \\
\text { levels on } \\
\text { day I }(\mathrm{pg} / \mathrm{mL})\end{array}$ & $\begin{array}{l}\text { Frozen VEGF } \\
\text { levels on } \\
\text { day } 21(\mathrm{pg} / \mathrm{mL})\end{array}$ \\
\hline I & 5.60 & 0.60 & 6.8 & 5.22 & 25.40 & 8.17 \\
\hline 2 & 9.21 & 1.59 & 8.41 & 5.47 & 3.95 & 3.00 \\
\hline 3 & 2.11 & 2.00 & 12.01 & 7.75 & 13.42 & 16.04 \\
\hline 4 & 1.33 & 1.334 & 1.12 & 0.63 & - & - \\
\hline 5 & 6.26 & 1.73 & 17.81 & 19.41 & - & - \\
\hline 6 & 6.35 & 2.83 & 4.94 & 3.08 & - & - \\
\hline 7 & 7.47 & 2.28 & 17.45 & 23.74 & - & - \\
\hline 8 & 2.12 & 2.69 & 13.04 & 11.24 & - & - \\
\hline 9 & 2.04 & 1.93 & 5.99 & 8.00 & - & - \\
\hline 10 & 3.06 & 3.53 & 4.54 & 3.63 & - & - \\
\hline 11 & 2.04 & 2.90 & - & - & - & - \\
\hline 12 & 13.77 & 10.32 & - & - & - & - \\
\hline 13 & 4.20 & 2.93 & - & - & - & - \\
\hline 14 & $|7.3|$ & 17.86 & - & - & - & - \\
\hline 15 & 4.06 & 4.63 & - & - & - & - \\
\hline 16 & 2.52 & 2.51 & - & - & - & - \\
\hline 17 & 8.27 & 11.50 & - & - & - & - \\
\hline 18 & 11.84 & 13.01 & - & - & - & - \\
\hline Coll & Col2 & Col3 & Col4 & Col5 & Col6 & Col7 \\
\hline Mean & 6.09 & 4.79 & 9.21 & 8.82 & 14.26 & 9.07 \\
\hline SD & 4.55 & 4.90 & 5.64 & 7.41 & 10.75 & 6.57 \\
\hline
\end{tabular}

significantly reduces the required sample volume. In addition, the sensitivity of the test is superior because fluorescence, rather than colorimetric measurement, is utilized. In our study, all the VEGF measurements were conducted using bead-based assay with standard VEGF concentrations as a positive control, which enhanced the validity of our results.

Recently, numerous studies evaluated the correlation between VEGF levels in the aqueous samples and severity of ocular ischemic process..$^{3,16-18}$ The next step after finding an appropriate correlation is to test whether the levels could be used to monitor the disease activity and response to treatment. ${ }^{15,16}$ Cytokines are usually not considered to be very stable after collection, which might artificially interfere with test results. ${ }^{15}$ Detected levels of cytokines may be affected by methods of storage or repeated freezing-thawing. ${ }^{14}$

However, there have been no studies evaluating the effect of storage on measurement of VEGF levels in aqueous samples. Our study is the first of its kind to test the stability of VEGF in aqueous humor samples and provides evidence of variation in VEGF measurement after 3 weeks of storage. This is consistent with results reported by Rosenling et al ${ }^{19}$ who observed a significant change in proteome-derived peptide profile in cerebrospinal fluid after storage for a week or 1 month, and with those of Aziz et $\mathrm{al}^{20}$ who reported a significant change in tumor necrosis factor alpha levels in plasma after storage, at $4^{\circ} \mathrm{C}$ or at $-70^{\circ} \mathrm{C}$ for 20 days in comparison to samples stored at $24^{\circ} \mathrm{C}$. This study's results are also consistent with earlier study results on fresh versus frozen urine sample peptide concentration. ${ }^{21}$

We can only speculate as to the mechanism of variation in VEGF measurements in aqueous samples. One possible mechanism is the presence of different proteases in the aqueous sample, which could cause a true decrease in VEGF measurement. ${ }^{22}$ Another possible mechanism could be the result of alteration of the binding of detector antibody used during the assay, possibly from degradation, and a change in configuration of amino acids in VEGF protein due to delayed measurements. ${ }^{19}$ The presence of soluble VEGF receptors in aqueous samples and the possibility of alteration in protein folding after freezing can increase the competitive binding affinity of other VEGF isoforms and increase VEGF levels observed in some samples.

In conclusion, this pilot study showed a statistically significant decrease in VEGF levels after storage for 3 weeks. Estimation of VEGF immediately after sample collection is recommended for accuracy. 


\section{Disclosure}

The authors report no conflicts of interest in this work.

\section{References}

1. Shweiki D, Itin A, Soffer D, Keshet E. Vascular endothelial growth factor induced by hypoxia may mediate hypoxia-initiated angiogenesis. Nature. 1992;359(6398):843-855.

2. Dvorak HF, Brown LF, Detmar M, Dvorak AM. Vascular permeability factor/vascular endothelial growth factor, microvascular hyperpermeability, and angiogenesis. Am J Pathol. 1995;146(5):1029-1039.

3. Adamis AP, Miller JW, Bernal MT, et al. Increased vascular endothelial growth factor levels in the vitreous of eyes with proliferative diabetic retinopathy. Am J Ophthalmol. 1994;118(4):445-450.

4. Hera R, Keramidas M, Peoc'h M, Mouillon M, Romanet JP, Feige JJ. Expression of VEGF and angiopoietins in subfoveal membranes from patients with age-related macular degeneration. Am J Ophthalmol. 2005; 139(4):589-596.

5. Pe'er J, Folberg R, Itin A, Gnessin H, Hemo I, Keshet E. Vascular endothelial growth factor upregulation in human central retinal vein occlusion. Ophthalmology. 1998;105(3):412-416.

6. Funk M, Kriechbaum K, Prager F, et al. Intraocular concentrations of growth factors and cytokines in retinal vein occlusion and the effect of therapy with bevacizumab. Invest Ophthalmol Vis Sci. 2009;50(3): 1025-1032.

7. Funatsu H, Yamashita H, Noma H, et al. Aqueous humor levels of cytokines are related to vitreous levels and progression of diabetic retinopathy in diabetic patients. Graefes Arch Clin Exp Ophthalmol. $2005 ; 243(1): 3-8$.

8. Roh MI, Kim HS, Song JH, Lim JB, Koh HJ, Kwon OW. Concentration of cytokines in the aqueous humor of patients with naïve, recurrent and regressed CNV associated with AMD after bevacizumab treatment. Retina. 2009;29(4):523-529.

9. Roh MI, Lim SJ, Ahn JM, Lim JB, Kwon OW. Concentration of cytokines in age-related macular degeneration after consecutive intravitreal bevacizumab injection. Graefes Arch Clin Exp Ophthalmol. 2010; 248(5):635-640.

10. Lai TY, Liu DT, Chan KP, Luk FO, Pang CP, Lam DS. Visual outcomes and growth factor changes of two dosages of intravitreal bevacizumab for neovascular age-related macular degeneration: a randomized, controlled trial. Retina. 2009;29(9):1218-1226.
11. Elshal MF, McCoy JP. Multiplex bead array assays: performance evaluation and comparison of sensitivity to ELISA. Methods. 2006;38(4): 317-323.

12. Young SH, Antonini JM, Roberts JR, Erdely AD, Zeidler-Erdely PC. Performance evaluation of cytometric bead assays for the measurement of lung cytokines in two rodent models. J Immunol Methods. 2008; 331(1-2):59-68.

13. Chalam KV, Balaiya S, Murthy RK. Accurate estimation of vascular endothelial growth factor levels in microsamples with a low-cost beadbased assay. Retina. 2010;30(5):815-819.

14. Flower L, Ahuja RH, Humphries SE, Mohamed-Ali V. Effects of sample handling on the stability of interleukin 6 , tumour necrosis factor-alpha and leptin. Cytokine. 2000;12(11):1712-1716.

15. Friebe A, Volk HD. Stability of tumor necrosis factor alpha, interleukin 6 , and interleukin 8 in blood samples of patients with systemic immune activation. Arch Pathol Lab Med. 2008;132(11):1802-1806.

16. Campochiaro PA, Choy DF, Do DV, et al. Monitoring ocular drug therapy by analysis of aqueous samples. Ophthalmology. 2009;116(11): 2158-2164.

17. Aiello LP, Avery RL, Arrigg PG, et al. Vascular endothelial growth factor in ocular fluid of patients with diabetic retinopathy and other retinal disorders. $N$ Engl J Med. 1994;331(22):1480-1487.

18. Wells JA, Murthy R, Chibber R, et al. Levels of vascular endothelial growth factor are elevated in the vitreous of patients with subretinal neovascularisation. Br J Ophthalmol. 1996;80(4):363-366.

19. Rosenling T, Slim CL, Christin C, et al. The effect of preanalytical factors on stability of the proteome and selected metabolites in cerebrospinal fluid (CSF). J Proteome Res. 2009;8(12):5511-5522.

20. Aziz N, Nishanian P, Mitsuyasu R, Detels R, Fahey JL. Variables that affect assays for plasma cytokines and soluble activation markers. Clin Diagn Lab Immunol. 1999;6(1):89-95.

21. Fiedler GM, Baumann S, Leichtle A, et al. Standardized peptidome profiling of human urine by magnetic bead separation and matrixassisted laser desorption/ionization time-of-flight mass spectrometry. Clin Chem. 2007;53(3):421-428.

22. Richardson MR, Price MO, Price FW, et al. Proteomic analysis of human aqueous humor using multidimensional protein identification technology. Mol Vis. 2009;15:2740-2750.
Clinical Ophthalmology

\section{Publish your work in this journal}

Clinical Ophthalmology is an international, peer-reviewed journal covering all subspecialties within ophthalmology. Key topics include: Optometry; Visual science; Pharmacology and drug therapy in eye diseases; Basic Sciences; Primary and Secondary eye care; Patien Safety and Quality of Care Improvements. This journal is indexed on Submit your manuscript here: http://www.dovepress.com/clinical-ophthalmology-journal

\section{Dovepress}

PubMed Central and CAS, and is the official journal of The Society of Clinical Ophthalmology (SCO). The manuscript management system is completely online and includes a very quick and fair peer-review system, which is all easy to use. Visit http://www.dovepress.com/ testimonials.php to read real quotes from published authors. 